BARTŁOMIEJ MICHALAK

Instytut Politologii UMK

\title{
Czy partie polityczne można liczyć, czyli o problemie relewancji politycznej
}

Z jawisko relewancji politycznej jest jednym z podstawowych zagadnień w obrębie teoii partii i systemów partyjnych. Relewancja to specyficzna właściwość przynależna pewnym partiom politycznym, dzięki której zajmują one szczególną pozycję w ramach złożonej i wielopoziomowej struktury interakcji międzypartyjnych nazwanej systemem partyjnym. Owa szczególna pozycja polega na możliwości kształtowania charakteru tych interakcji, a w konsekwencji na kierunkowanie całego systemu. Ujmując sprawę najprościej jak się da, możemy powiedzieć, że partia relewantna to taka partia, której istnienie i działalność na scenie politycznej jest znaczące nie tylko dla niej samej (i, co oczywiste, jej zwolenników), ale również dla pozostałych uczestników rywalizacji międzypartyjnej. Innymi słowy, jej obecność wpływa na funkcjonowanie systemu partyjnego jako całości, współdeterminując charakter i kierunek jego ewolucji. Przy czym ów wpływ należy traktować jako proces złożony i nie chwilowy.

Relewancja polityczna jako kategoria badawcza pojawiła się w literaturze politologicznej przede wszystkim dzięki cytowanej powyżej pracy włoskiego politologa Giovanniego Sartoriego, znanego polskiemu czytelnikowi z fundamentalnej dla politologii pracy pt. Teoria demokracji13. To on jako jeden z pierwszych ją scharakteryzował i upowszechnił. Dokonał podziału wszystkich partii politycznych na takie, które faktycznie uczestniczą w rządzeniu, bądź są zdolne do odgrywania roli efektywnej opozycji oraz te, które takich możliwości nie mają. Tylko ta pierwsza grupa może w sposób trwały i powtarzalny wpływać na formułowanie i realizację polityki państwa. W związku z tym jedynie partie z tej grupy mają dla funkcjonowania systemu politycznego realne znaczenie lub inaczej mówiąc są politycznie „istotne”, czyli właśnie relewantne ${ }^{14}$.

Jak w przypadku wielu ważnych dla nauki odkryć, stało się to w zasadzie trochę przypadkiem i niejako na uboczu zasadniczych rozważań. Cytowany fragment pochodzi bowiem z książi, którą na pierwszy rzut oka można zaliczyć do kategorii podręczników. Dobór zagadnień, klarowny układ treści, poprawna systematyka zdają się utwierdzać w tym przeświadczeniu. To, co pracę Sartoriego jednak odróżnia od klasycznych podręczników, to dokładne analizowanie napotykanych zagadnień. Celem Sartoriego nie jest

13 G. Sartori, The Theory of Democracy Revisited, Chatham House Publishers, Chatham 1987. Polskie wydanie, w przekładzie Piotra Amsterdamskiego i Daniela Grinberga, ukazało się nakładem Wydawnictwa Naukowego PWN w 1998 r.

14 A. Antoszewski, Relewancja partii politycznej, w: Encyklopedia politologii. t. 3. Partie i systemy partyjne, red. A. Antoszewski, R. Herbut, Kraków 1999, s. 212-213. 
prezentowanie dziesiątek definicji i orientacji teoretycznych, z których czasami autorzy 0 ambicjach teoretycznych starają się zbudować (z różnym skutkiem) „własną" definicję opisywanego zjawiska, stosując, jakże użyteczną w tej sytuacji, metodę kompilacyjną. Otóż Sartori stara się dotrzeć do ich differentia specifica, uchwycić, a następnie wydobyć na powierzchnię istotę analizowanych przez siebie pojęć. Tak też stało się w przypadku relewancji. Problem ten pojawił się bowiem na marginesie rozważań na temat użyteczności i efektywności podejścia ilościowego stosowanego do klasyfikowania systemów partyjnych.

Tradycja klasyfikowania systemów partyjnych w oparciu o kryterium ilościowe wywodzi się już od Maxa Webera, ale dopiero Maurice Duverger zaproponował pełną, opartą wyłącznie na tym kryterium klasyfikację, która w następnych dekadach zrobiła prawdziwą furorę. Zgodnie z jego propozycją wszystkie istniejące na świecie systemy partyjne można zaliczyć do jednej z trzech klas: jednopartyjnych, dwupartyjnych i wielopartyjnych ${ }^{15}$. Koncepcja ta o tyleż genialna, co prosta, wzbudziła w środowisku naukowym liczne dyskusje. Jedni ją propagowali, inni krytykowali, ale przez długie lata stanowiła punkt wyjścia dla jakichkolwiek dalszych analiz. Na jej bazie powstało zresztą wiele różnych mutacji. Niestety pomiędzy wzrostem liczby różnego rodzaju propozycji a powiększaniem wiedzy na temat funkcjonowania systemów partyjnych nie zachodził związek o charakterze liniowym. Co więcej, choć klasyfikacja Duvergera na pierwszy rzut oka wydaje się logiczna, to po głębszej analizie nie wytrzymuje jednak krytyki. Abstrahując nawet od tego, czy możemy w ogóle nazywać systemem zbiór, w którym znajduje się tylko jeden element, najpoważniejszym zarzutem pod względem tej klasyfikacji jest konieczność uwzględnienia w tej samej kategorii takich systemów partyjnych jak: francuski po 1958 r., włoski do 1993 r. czy niemiecki po 1949 r. Z pewnością wszystkie one są wielopartyjne — tzn. więcej niż tylko dwie partie mają możliwość zdobycia i sprawowania władzy państwowej i żadna z nich nie jest zdolna sprawować władzy w pojedynkę - ale na tym wszystkie podobieństwa się kończą. W istocie taka typizacja nie mówi nam prawie nic na temat funkcjonowania tych systemów. Nie powinno więc dziwić, że coraz częściej zaczęto rozważać odejście od kryterium ilościowego jako małowartościowego poznawczo. Od tego miejsca zaczyna swoje rozważania Sartori.

Zdaniem włoskiego politologa nie należy pochopnie rezygnować z podejścia ilościowego. Nawet laik jest przecież w stanie zauważyć, że liczba partii obecnych w systemie musi mieć znaczenie przy określaniu liczby potencjalnych wariantów koalicyjnych. Teoretycznie zupełnie niewielki wzrost liczby partii powoduje bardzo istotne konsekwencje polityczne przyczyniając się do znacznego skomplikowania przetargów koalicyjnych. Przykładowo w parlamencie, w którym reprezentacje posiadają cztery ugrupowania, sformowanych może zostać 15 różnych gabinetów, podczas gdy pojawienie się na tej

15 Zob. M. Duverger, Les partis politiques, Paris 1951. 
arenie jeszcze jednej partii zwiększa tę wartość aż do 31 alternatywnych rozwiązańn'. Tak więc dysponując tylko i wyłącznie danymi na temat liczby partii w parlamencie otrzymujemy znaczną ilość informacji na temat całego systemu partyjnego takich, jak poziom jego fragmentaryzacji i koncentracji, czy o liczbie możliwych konfiguracji partyjnych, które Sartori określa mianem „interakcyjnych strumieni”. Charakter tych interakcji zależy w pierwszej kolejności od ogólnej liczby ugrupowań biorących w nich udział. To zaś warunkuje później sposób, w jaki formują się, funkcjonują i rozpadają koalicje rządowe.

Z drugiej jednak strony, w praktyce politycznej nie spotyka się sytuacji, aby wszystkie partie obecne w parlamencie brały udział w procesie przetargów koalicyjnych. Znaczenie określonych stronnictw w systemie nie wynika bowiem wyłącznie z faktu ich obecności na forum parlamentu. To, że danemu ugrupowaniu udało się wprowadzić swoich przedstawicieli do organu ustawodawczego nie powoduje, że partia taka automatycznie staje się znacząca politycznie, choć zdecydowanie zwiększa to jej możliwości działania, przede wszystkim zaś daje bezpośredni dostęp do władzy. W parlamentach spotkać można zarówno duże, silne wyborczo i stale obecne na scenie politycznej ugrupowania, jak również różnego rodzaju polityczne „efemerydy” oraz partie zupełnie małe, dysponujące czasami kilkunastu czy nawet kilkuosobową reprezentacją.

Okazuje się więc, że liczba partii ma znaczenie, ale 0 ich sile decyduje przede wszystkim liczebność poszczególnych frakcji, ta zaś stanowi bezpośrednią konsekwencję rozmiaru poparcia wynikającego z liczby wyborców, którzy podczas głosowania zdecydowali się oddać swoje głosy na przedstawicieli tych partii. Im więcej głosów, tym większa jest zdolność wywierania wpływu na proces przetargów politycznych odbywających się na forum parlamentu. Ponownie jednak musimy sobie uświadomić, że to nie liczba głosów, ale liczba mandatów kontrolowanych przez daną partię w parlamencie stanowi o sile danej partii. Oczywiście w warunkach systemu demokratycznego jeden parametr jest ściśle zależny od drugiego, i nie może być inaczej, jednak reguły systemu wyborczego mogą, w zależności od przyjętej formuły wyborczej, wysokości progów, kształtu i wielkości okręgów, metod przeliczania głosów na mandaty itd., doprowadzić do znaczących „zakłóceń” w procesie transformacji głosów na mandaty, co w literaturze politologicznej nazywane jest deformacją wyniku wyborów.

Czy to oznacza, że o relewancji partii politycznych decyduje wyłącznie wielkość jej frakcji parlamentarnej? Na tak postawione pytanie musimy odpowiedzieć jednak przecząco. W praktyce politycznej występowały i występują bowiem przypadki, dotyczy

16 Jest to liczba wszystkich teoretycznie możliwych konfiguracji rządowych. W przypadku gabinetów tylko i wyłącznie koalicyjnych będzie to 11 dla czterech ugrupowań i 26 dla pięciu. Z kolei jeśli wziąć pod uwagę wszystkie możliwe konfiguracje (permutacje), a więc nie tylko skład koalicji, ale również rolę i hierarchię poszczególnych jej uczestników, to wartości te wzrosną odpowiednio do 24 i 120. R. Herbut, Systemy partyjne w Europie Zachodniej - ciągłość i zmiana. Studium porównawcze, Wrocław 1996, s. 157. 
to zwłaszcza państw korzystających z proporcjonalnego systemu wyborczego, gdzie ugrupowanie może zdobyć najwięcej głosów i/lub mandatów, ale mimo tego od bezpośredniego sprawowania władzy zostaje odsunięte wskutek działań swoich konkurentów politycznych na arenie przetargów koalicyjnych. Dla jasności wywodu rozważmy taki oto przykład. W liczącym 100 deputowanych parlamencie zasiadają przedstawiciele trzech stronnictw (nazwijmy je partiami $A, B$ i $C$ ), przy czym partia $A$ dysponuje 46 mandatami, partia $B 7$ mandatami, a partia $C 47$ mandatami. Spróbujmy teraz określić ich silę polityczną: czy sekwencja $C>A>B$ nie narzuca się jako pierwsza? Nawet jeśli uznamy, że różnica pomiędzy $A$ i $C$ jest tak mała, że $w$ istocie pomijalna, to nadal przepaść pomiędzy tymi dwoma ugrupowaniami a partią $B$ wydaje się przemawiać za tezą, że mamy tutaj do czynienia tak naprawdę tylko $z$ dwoma graczami. Czy tak jest jednak w rzeczywistości? Zauważmy, że żadna z tych partii nie dysponuje wystarczającą liczbą deputowanych, by mogła sama sprawować władzę. Nikt nie ma większości (by ją uzyskać należatoby dysponować 51 głosami) i nie jest w stanie sprawować rządów inaczej, niż przy współudziale którejś $z$ dwóch pozostałych partii. W ten sposób realna siła każdej partii w naszym przykładzie jest dokładnie taka sama. Każda z tych partii pełnić może bowiem rolę „języczka u wagi" i jest w stanie zmienić układ rywalizacji. W teorii wyboru społecznego powiemy, że każda z tych partii ma pozycję gracza "krytycznego”. Dlaczego tak się dzieje? Otóż siła danego ugrupowania nie zależy bowiem od jego liczebności, ale od jego niezbędności w procesie tworzenia danej koalicji większościowej. W tym sensie wszystkie ugrupowania, również małe, mają takie same znaczenie.

Tyle, aż tyle i tylko tyle, informacji na temat systemu partyjnego otrzymujemy wykorzystując podejście ilościowe. Skomplikujemy teraz nieco nasz przykład zakładając, że partia $C$ w swoich dokumentach programowych i enuncjacjach przywódców prezentuje bardzo radykalny program zmiany rzeczywistości. W istocie program ten jest bardzo daleki od poglądów, jakie w tych samych sprawach prezentują partie $A$ i $B$. Używając precyzyjnego aparatu pojęciowego powiemy, że w tej sytuacji pomiędzy partami $A$ i $B$ $z$ jednej strony oraz $C$ z drugiej, istnieje duży dystans ideologiczny, który w naturalny sposób utrudnia, a być może nawet uniemożliwia zawarcie jakiegokolwiek porozumienia politycznego pomiędzy tymi stronnictwami. Załóżmy teraz dalej, że program partii $C$ jest radykalny nie tylko w swej treści, ale dla swojej realizacji wymaga również przebudowy systemu politycznego włącznie ze zmianą dotychczasowych mechanizmów decyzyjnych i aktorów w nich uczestniczących. Partia $C$ nie jest więc ugrupowaniem opozycyjnym w klasycznym sensie tego słowa, a prezentuje się jako partia występująca przeciw całemu systemowi. To zaś wyklucza nie tylko sformowanie jakiegokolwiek porozumienia koalicyjnego przy jej współudziale, ale najprawdopodobniej oznacza również brak wspótpracy na innych płaszczyznach interakcji międzypartyjnych, do pełnej izolacji włącznie. Krótko mówiąc partia $C$ przestaje mieścić się w polu akceptacji politycznej partii $A$ i $B$.

Jak w tej sytuacji określimy siłę poszczególnych partii? Czy nadal jest ona taka sama? Już na pierwszy rzut oka widać, że nie. W tym przypadku koalicja zostanie za- 
warta przez $A$ i $B$. Bezalternatywność tego układu powoduje, że partia $B$ gwałtowanie zyskuje na istotności. Tak naprawdę przestaje mieć znaczenie to iloma mandatami będzie dysponować, byle tylko liczba ta wystarczyła do utworzenia większości. Co więcej, jeśli $A$ i $C$ znajdują się dokładnie na przeciwnych biegunach rywalizacji politycznej (np. jedna jest zdecydowanie prawicowa a druga lewicowa), to siła $B$ zwiększa się jeszcze bardziej. Symptomatyczny jest w tym kontekście status partii obrotowych, zwanych również piwotalnymi bądź zawiasowymi. Ugrupowania te charakteryzują się z reguły centralnym położeniem $w$ ramach politycznego spektrum, a z tego powodu jako partner koalicyjny są akceptowane przez wszystkich graczy, zarówno z lewicy jak i z prawicy. Relewancja polityczna takich ugrupowań, ze względu na ich częste uczestnictwo w rządach, jest czasami o wiele większa niż ugrupowań wyborczo silniejszych i politycznie dominujących.

Jak widać, mimo że kryterium związane z rozmiarem poparcia i liczbą miejsc w parlamencie jest istotne, to jednak nie można go rozpatrywać w oderwaniu od pozostałych elementów związanych ze strukturą danego systemu partyjnego oraz charakterem rywalizacji politycznej, jaka toczy się w jego ramach. Co prawda przekroczenie progu reprezentacji otwiera partii drogę do wielkiej polityki, jednak to czy dane ugrupowanie dysponuje taką pozycją w ramach systemu partyjnego, która pozwala jej na odgrywanie znaczącej roli w procesie negocjacji parlamentarnych zależy od spełnienia przez nią dodatkowych warunków. Stanowi to pewien problem przy próbie dokładnej operacjonalizacji pojęcia relewancji. Okazuje się bowiem, że nie sposób dokonać tego w oparciu o uniwersalną formułę matematyczną ${ }^{17}$. Dlatego właśnie zdaniem Sartoriego partie polityczne należy liczyć „inteligentnie”.

To, co ma najistotniejsze znaczenie w procesie interakcji międzypartyjnych, to stopień prawdopodobieństwa, z jakim dana partia może być brana pod uwagę jako potencjalny uczestnik jednej bądź więcej koalicji rządowych. Teoretycznie partia może być mała (biorąc pod uwagę wielkość jej frakcji parlamentarnej), ale dysponuje silną zdolnością negocjacyjno-koalicyjną i na odwrót. Pytaniem zasadniczym jest na ile ten potencjał przekładalny jest na realną siłę polityczną? Na początku więc łatwiej będzie wykazać, które ugrupowania w ogóle takowym potencjałem nie dysponują. Zdaniem włoskiego politologa te partie, które nigdy nie były brane pod uwage jako realni partnerzy jakiejkolwiek koalicji rządowej, z pewnością można zaliczyć do nierelewantnych. A contrario jako relewantne liczyć musimy takie partie, bez względu na to jak "małe" by były, które znajdują się w takiej sytuacji, że mogą wpływać na co najmniej jedną potencjalnie możliwą koalicję rządową (pierwsza reguła relewancji Sartoriego). Inaczej ujmując, dysponują „potencjałem koalicyjnym”, czyli faktyczną a nie tylko teoretyczną możliwością uczestnictwa w koalicjach rządowych, z których przynajmniej cześć została w praktyce zawiązana. Potencjał ten istnieje, jeśli dane ugrupowanie, bez względu na

17 R. Herbut, dz. cyt., s. 175. 
jego rozmiar rozumiany tutaj jako liczba reprezentantów w parlamencie lub/i wielkość poparcia, jest brane pod uwage jako potencjalny partner polityczny, tzn. znajduje się w pozycji umożliwiającej wpływanie na kształt co najmniej jednej z teoretycznych koalicji rządowych. Oznacza to, że dane ugrupowanie jest organizacyjnie i politycznie przygotowane do sprawowania władzy w państwie i/lub jako takie jest postrzegane przez pozostałych uczestników interakcji międzypartyjnych. To zaś umożliwia jej odgrywanie istotnej roli w systemie partyjnym ${ }^{18}$. Inaczej rzecz ujmując, aktywnie uczestniczy ona w procesie przetargów koalicyjnych.

Zasada ta ma jednak swoje ograniczenia. Obejmuje bowiem tylko te partie, które pod względem ideologicznym są do zaakceptowania przez pozostałych uczestników rywalizacji politycznej. Nie bierze tym samym pod uwagę partii relatywnie dużych, które z tych czy innych powodów nie uczestniczą w przetargach gabinetowych a pozostają w permanentnej opozycji. Partie takie dysponować mogą przecież wystarczającą liczbą miejsc w legislaturze, by wytworzyć z innymi ugrupowaniami większość gwarantującą sprawowanie władzy lub przynajmniej być w procesie tym branym pod uwagę. Jednak ze względów politycznych są one izolowane przez pozostałych aktorów sceny politycznej. Tak więc, mimo że rozmiar poparcia predysponuje je do aktywnego uczestnictwa w przetargach koalicyjnych, to ich antysystemowy charakter powoduje, że ten „ewentualny" potencjał koalicyjny spada do zera. Czy to oznacza, że również ich znaczenie w systemie jest równie niskie? Biorąc pod uwagę fakt, że partia taka nie będzie mogła współtworzyć koalicji gabinetowych i nie będzie brana pod uwagę jako partner w jakichkolwiek przetargach międzypartyjnych, należałoby odpowiedzieć twierdząco. Nie jest to jednak prawdą. Wróćmy ponownie do wcześniej rozważanego przykładu. Poprzednio stwierdziliśmy, że antysystemowość partii $C$ uniemożliwia jej wejście w skład jakiejkolwiek większości rządowej. To z kolei determinuje pozycję partii $B$, której rola w systemie partyjnym wzrasta w sposób nieproporcjonalny biorąc pod uwagę wielkość jej frakcji i poparcia wyborczego. Co prawda ugrupowania antysystemowe z reguły nie są uwzględniane jako potencjalni koalicjanci, to jednak dzięki kontrolowaniu określonej liczby miejsc w legislaturze są w stanie skutecznie zablokować sformowanie niektórych koalicji większościowych. Pozostając nadal przy naszym przykładzie, to właśnie obecność w parlamencie partii $C$ spowodowała, że jedyną realną formułą koalicyjną stał się sojusz $A$ i $B$. To ona właśnie przesądziła o kształcie tej interakcji.

W przeszłości we Włoszech i we Francji partie komunistyczne były zdolne zebrać jedną trzecią wszystkich ważnie oddanych w wyborach głosów, a mimo tego przez ćwierć wieku ich rządowy potencjał koalicyjny wynosił zero. Chociaż partie te nie uczestniczyły bezpośrednio w sprawowaniu władzy, to jednak cały czas były nie tylko obecne, ale i bardzo aktywne na politycznej scenie swoich państw. Odmawianie im ja-

18 Demokracje zachodnioeuropejskie. Analiza porównawcza, A. Antoszewski, R. Herbut (red.), Wrocław 1997, s. 138. 
kiejkolwiek relewancji byłoby więc absurdalne. Z tego też powodu pierwsze kryterium relewancji (a właściwie nie-relewancji) musi zostać uzupełnione o kolejną zasadę. Bazuje ona na identyfikacji możliwości wykorzystania siły zastraszenia przez partie antysystemowe, a dokładnie rzecz ujmując ich „potencjału szantażu politycznego” względem tradycyjnych ugrupowań politycznych. W tym przypadku partia kwalifikuje się jako relewantna, mimo iż nie jest brana pod uwagę w procesie przetargów koalicyjnych, jeżeli rezultatem jej zaistnienia lub funkcjonowania była jakakolwiek zmiana dotychczasowych wzorców interakcji pomiędzy pozostałymi ugrupowaniami relewantnymi (tzw. druga reguła relewancjil. Inaczej ujmując, ich istnienie powoduje, że niektóre wcześniejsze taktyki koalicyjne muszą zostać porzucone lub zmodyfikowane $w$ reakcji na pojawienie się partii antysystemowej. W ten sposób obecność takich partii w parlamencie w bezpośredni sposób oddziałuje na charakter międzypartyjnych interakcji, gdyż zmusza pozostałych aktorów sceny politycznej do zmiany stosowanych do tej pory strategii politycznych. Przykładem tego wpływu może być ucieczka partii umiarkowanej lewicy lub prawicy do centrum i próba przejęcia tego elektoratu na skutek pojawienia się na obrzeżu systemu ugrupowania antysystemowego czy formowanie rządów tzw. wielkich koalicji. Sytuacja taka w szczególności dotyka stronnictwa blisko usytuowane (sąsiadujące) na osi prawica-lewica względem partii izolowanych ${ }^{19}$. W ten sposób, pomimo że dana partia zostaje wyłączona przez pozostałych graczy z procesu przetargów koalicyjnych i nie jest brana pod uwage jako możliwy do zaakceptowania sojusznik polityczny, to jednak jej istnienie, zachowanie lub poparcie wpływa na przebieg interakcji pomiędzy pozostałymi ugrupowaniami zmieniając w konsekwencji mechanizm funkcjonowania całego systemu.

Zaproponowana przez Sartoriego propozycja „liczenia partii” nazwana później w literaturze przedmiotu "testem relewancji”, choć elegancka w formie i przekonująca w treści, to jednak nie jest pozbawiona pewnych wad. Jak pamiętamy z lektury tekstu, jedną z istotniejszych przesłanek leżących u podstaw opracowanej przez niego koncepcji, było silnie umotywowane założenie, że zjawisko relewancji politycznej nie jest zdeterminowane tylko i wyłącznie rozmiarem poparcia, a dokładniej rzecz ujmując liczbą miejsc w parlamencie będących w dyspozycji poszczególnych ugrupowań. Jeśli jednak zastanowić się dokładniej, to okazuje się, że propozycja ta cały czas opiera się jednak na kryterium rozmiaru partii jako zmiennej warunkującej jej rolę w systemie partyjnym. Zdaniem Ryszarda Herbuta to przede wszystkim rozmiar izolowanych politycznie stronnictw komunistycznych we Włoszech i we Francji zmusił Sartoriego do szukania alternatywnej, wobec zmiennej potencjału koalicyjnego, zasady liczenia partii, która umożliwiłaby mu włączenie tych właśnie ugrupowań do kategorii relewantnych. Kryterium rozmiaru jest szczególnie istotne właśnie w przypadku ugrupowań „testowanych” w oparciu o potencjał szantażu politycznego. W jakiż inny sposób, pyta Herbut, partie tego typu

19 R. Herbut, dz. cyt., s. 175. 
mogłyby zmusić pozostałe ugrupowania do zmiany strategii rywalizacyjnych inaczej niż przy pomocy znacznego odsetka popierającego je elektoratu? Żadna z poważnych partii politycznych nie uzależniałaby przecież swoich strategii politycznych od funkcjonowania marginalnych wyborczo ugrupowań protestu ${ }^{20}$.

Tak więc „test relewancji” Sartoriego posiada duży walor praktyczny w sytuacji, gdy chcemy odróżnić partie odgrywające istotną rolę w systemie od tych, które stanowią tło rywalizacji politycznej. Jednak nawet w tej sytuacji ocena relewancji, jaką dzięki niemu uzyskujemy, może okazać się niewystarczającą. Test traktuje wszystkie partie istotne dla systemu w ten sam sposób i ich nie hierarchizuje. Co prawda przy jego pomocy możemy dokonać uporządkowania partii ze względu na posiadanie przez nie takiej cechy jak relewancja (jest to pomiar na poziomie nominalnym), ale już nie ze względu na jej natężenie (pomiar na poziomie porządkowym). Tymczasem jest przecież oczywiste, że stopień relewancji jednych ugrupowań ma zupełnie inny wymiar niż pozostałych. Wśród partii istotnych politycznie mogą bowiem występować tzw. ugrupowania inicjujące koalicję, odgrywające główną rolę w procesie przetargów koalicyjnych oraz partie ją dopełniające. Potencjał koalicyjny tych drugich pozostaje dużo słabszy niż ma to miejsce w przypadku partnerów inicjujących. W tym przypadku ocena statusu tych partii opierać się musi na kryterium pozycji zajmowanej w ramach przetargów koalicyjnych, czyli ich faktycznej zdolności do wpływania na kształt formowanych gabinetów ${ }^{21}$. Innego znaczenia politycznego nabiera partia, która tworzy rząd samodzielnie a odmiennego ta, która zmuszona jest szukać koalicjanta. Również w ramach gabinetów koalicyjnych siła poszczególnych ugrupowań jest zróżnicowana i zależy także od liczby podmiotów ją tworzących (koalicja minimalnie zwycięska versus koalicja nadwyżkowa), charakteru porozumienia (np. rząd szerokiego porozumienia, rząd tymczasowy, gabinet "fachowców” itd.) oraz potencjału koalicyjnego każdego z tych ugrupowań (silniejsza jest pozycja tych koalicjantów, którzy są w stanie stworzyć alternatywną większość wchodząc w sojusz z inną partią, a więc pełnią rolę „jęzzyczka u wagi"). Relewancja poszczególnych ugrupowań zależy też od faktu czy gabinet, w którym ta partia partycypuje (jednopartyjny lub koalicyjny) dysponuje większością umożliwiającą jej efektywne rządzenie. Ugrupowania tworzące rząd, który ma zapewnione poparcie większości parlamentarnej dysponują znacznie większą relewancją niż w przypadku, gdy gabinet taki jest zależny od poparcia zewnętrznego bądź ze względów politycznych lub prawno-instytucjonalnych nie ma dla niego alternatywy.

Niestety nawet ta technika ma swoje istotne ograniczenia poznawcze. Może bowiem znaleźć zastosowanie tylko i wyłącznie do tych ugrupowań, które współtworzą koalicje rządowe, a więc wypełniają warunki pierwszej zasady relewancji, czyli dysponują odpowiednim potencjałem koalicyjnym. Co w takim razie z partiami wykluczonymi

Tamże, s. 176.

Demokracje..., s. 139-140. 
z procesu przetargów koalicyjnych ze względu na swoją antysystemowość, dysponującymi jednak określonym poziomem potencjału szantażu politycznego? Jego poziom, podobnie jak w przypadku ugrupowań posiadających potencjał koalicyjny, też przecież musi być zróżnicowany. 0 ile jednak w przypadku partii aktywnie uczestniczących w procesie przetargów koalicyjnych rozmiar partii ma istotne, ale nie decydujące znaczenie dla oszacowania jej faktycznej wielkości (istotne są również inne czynniki takie np. jak dystans ideologiczny itd.), to dla ugrupowań z procesu tego wyłączonych jedynym i zarazem rozstrzygającym kryterium jest odsetek miejsc kontrolowanych w parlamencie. Ponieważ programowo partie te sytuują się poza dotychczasowym spektrum rywalizacji partyjnej ich polityczne przesłanie może wywrzeć pożądany skutek jedynie w sytuacji, gdy spotka się z akceptacją znacznej części wyborców. To z kolei przekłada się na odpowiednią liczebność frakcji parlamentarnej. Tylko w ten sposób mogą one realnie wpływać na pozostałych uczestników sceny politycznej w sposób określony przez Sartoriego jako „szantaż polityczny”. Na bazie tej obserwacji można sformułować ogólniejszą zasadę, zgodnie z którą poziom potencjału szantażu politycznego rośnie wprost proporcjonalnie do wartości udziału danej partii w ogólnej puli mandatów.

Z powyższych rozważań jasno wynika, że relewancja polityczna jest kategorią trudno mierzalną. Dla wielu politologów zajmujących się teorią partii politycznych problematyka relewancji politycznej to nadal dobry temat do dyskusji. Cały czas istnieja rozbieżności w kwestii jednoznacznego ustalenia stopnia relewancji politycznej konkretnych ugrupowań. Poszczególni autorzy różnie określają próg, od którego się ona rozpoczyna. W istocie proponują więc swoje własne "reguły liczenia"22. Pamiętajmy jednak, że celem Sartoriego było zaproponowanie nowej klasyfikacji ilościowej systemów partyjnych, a nie badanie relewancji poszczególnych partii, i w tym kierunku szła jego koncepcja operacjonalizacji tego zjawiska. Problem relewancji był więc dla niego ważnym, ale tylko elementem szerszej koncepcji. W tym sensie zaproponowane przez niego zasady spełniły swoją rolę. Swój cel, włoski politolog, z ich pomocą zrealizował. Udało mu się zbudować nową, dobrze uzasadnioną i udokumentowaną typologię systemów partyjnych o wysokich walorach poznawczych. Została ona zresztą bardzo dobrze przyjęta i nadal przez wielu badaczy uznawana jest za najważniejszą i najpetniejszą typologię systemów partyjnych, jaką kiedykolwiek wymyślono ${ }^{23}$. 0 jej wartości może świadczyć rów-

22 Nie inaczej postąpił również autor tej glosy wychodząc z założenia, że skoro relewancja jest zjawiskiem wysoce złożonym, to naturalnym stanem rzeczy powinno być jej postrzeganie w całej swojej „złożoności". Dlatego właśnie badanie relewancji politycznej należy prowadzić na wszystkich jej poziomach. Dopiero uzyskane w ten sposób wyniki pozwolą na uchwycenie specyfiki tego zjawiska w jego całościowym, wielopłaszczyznowym aspekcie. Czytelnika zainteresowanego tą propozycją odsyłam do: B. Michalak, Partie protestu w Europie Zachodniej, Toruń 2008, s. 68-104 inn.

23 Wyróżnił on w sumie siedem klas (podział wg kryterium ilościowego) i dziewięć typów (podział wg kryterium jakościowego) systemów partyjnych. Krzyżując oba te kryteria udało mu się zbudować wielowymiarową typologię obejmującą swym zasięgiem również systemy nierywalizacyjne. Na ten temat zob. G. 
nież to, że liczy ona sobie już ponad 30 lat. Pierwsze wydanie cytowanej książki miało bowiem miejsce w 1976 r. i od tego czasu jest ona systematycznie wznawiana. Niestety, jak do tej pory, ta klasyczna już dla politologii praca, nie doczekała się przekładu na język polski. Być może publikowany właśnie na łamach „Dialogów Politycznych” fragment przyczyni się do zmiany tego stanu rzeczy.

B ART七OMIE J MICHALAK

Sartori, Parties and Party Systems, ECPR Press, Essex 2005, s. 110-113, 251-261; Demokracje..., s. 164169; B. Michalak, dz. cyt., s. 56-58. 